\title{
CONTRIBUTIONS OF ISLAMIC CIVILIZATION TO THE MATHEMATICS DEVELOPMENT
}

\author{
Liya Khaulah Asy-Syaimaa' Hussain \\ Pusat Pengajian Sains Matematik, Fakulti Sains dan Teknologi, \\ Universiti Kebangsaan Malaysia, 43600 UKM Bangi, Selangor, Malaysia \\ E-mail: khaulah2391@gmail.com \\ Ahmad Faizuddin Ramli \\ Departement of Social Science, Faculty of Humanities and Social Science \\ Nilai University, 71800 Nilai, Negeri Sembilan, Malaysia \\ E-mail: faizuddin@ nilai.edu.my
}

\begin{abstract}
The development of Islamic civilization goes hand in hand with physical and spiritual development. This development can be highlighted since the beginning of the golden age of Islam that witnessed the development of knowledge by Muslims scholars in various disciplines, including mathematics. The discourse in mathematical science only involves numbers, letters, and formulas. Muslims scholars took them as instruments to manifest the greatest of God. This paper investigates the contributions of Muslim scholars in Mathematics. The method of this study is qualitative through literature review. The resulting study found that the Quran became a source of inspiration to Muslim scholars in mathematics that form the branch of knowledge such as number theory, arithmetic, algebra, and geometry. This paper also promotes Islamization of Knowledge and its necessity to solve current Muslim world's educational problems.
\end{abstract}

\section{Keywords:}

Islamic civilization; mathematic; history of mathematic

\begin{abstract}
Abstrak
Perkembangan peradan Islam berjalan seiring dengan pembangunan fisik dan spiritual. Hal ini dapat diamati sejak awal zaman keemasan Islam yang sedang mengalami perkembangan pengetahuan yang dikembangkan oleh para cendekiawan muslim dalam berbagai disiplin keilmuan, termasuk matematika. Wacana para cendekiawan muslim dalam ilmu matematika melibatkan berbagai nomor, huruf, dan formula, yang digunakan sebagai instrumen untuk manifestasi pendekatan diri kepada Tuhan.Artikel ini berusaha membahas sumbangan para cendekiawan muslim terhadap perkembangan ilmu Matematik. Metode yang digunakan dalam kajian ini adalah bersifat kualitatif melalui kajian literatur dan pendekatan sejarah. Hasil kajian ini menemukan bahwa Alquran menjadi sumber inspirasi bagi para sarjana muslim dalam bidang matematik yang kemudian membentuk rumusan dalamdisiplin ilmu pengetahuan ini seperti teori bilangan, aritmatika, aljabar, dan geometri. Artikel ini juga berusaha mempromosikan proses Islamisasi pengetahuan dan pentingnya Islamisasi pengetahuan dalam menyelesaikan masalah pendidikan umat Islam dewasa ini.
\end{abstract}

Kata Kunci:

Peradaban Islam; matematika; sejarah matematika

DOI: $10.15575 / \mathrm{jw} . v 2 \mathrm{i} 2.1450$

Received: August 2017; Accepted: December 2017; Published: December 2017 


\section{A. INTRODUCTION}

Islam has its own golden history almost in every sector of knowledge. The main theological resource of Islam, al-Quran, also gives the utmost emphasize on pursuing knowledge. Muslim scholars from the past were very much aware of this instruction given by Allah s.w.t and they were very much captivated onto that. They developed many ideas and theories in the field of knowledge. The glorious of Islamic civilization era indicates the emergence of many Muslim scholars in various fields particularly mathematics led by al-Khwarizmi (780-850), Thabit bin Qurrah (826-901), Abu al-Karaji (953-1029), al-Hazen (965-1040), and Omar Khayyam (1048-1131). ${ }^{1}$ The development of Mathematical science is significant in the reign of the Abbasid empire. In this period, Islamic civilization forges a golden age, particularly after the establishment of the Bayt al-Hikmah (House of Wisdom) by caliph Ma'mun who ruled during 813-833, was destined to play a pivotal role in the development of Mathematics. ${ }^{2}$

The Bayt al-Hikmah, which would last more than 200 years, contained large-scale translation project of many ancient works from Greek manuscripts which were obtained through treaties. By the end of the 9th century, the major works of the Greeks had been translated. In addition, they learned the mathematics of the Babylonians and the Hindus. ${ }^{3}$

Therefore, Morris Kline a Western scholar denies the contribution of Muslims scholar in mathematics and claimed the works were taken from Hindus and Greek mathematics before expending it to Europe. ${ }^{4}$ Criticizing Kline's argument, the Muslims scholar not

\footnotetext{
1 M Wodzicki, "Early History of Algebra: A Sketch," Math 160, 2005, 1-2.

${ }^{2}$ M Wodzicki, "Early History of Algebra.", 1.

${ }^{3}$ Judith V Grabiner, "The Centrality of Mathematics in the History of Western Thought," Mathematics Magazine 61, no. 4 (October 1988): p.222, doi:10.2307/2689357. See also Wodzicki, "Early History of Algebra: A Sketch", 1.

${ }^{4}$ Morris Kline, Mathematics in Western Culture (London: Oxford Press, 1953), 93.
}

simply take 100 percent the work from other civilization. They did not stop with assimilation, but innovated and criticized those materials. ${ }^{5}$ Islamic mathematicians did far more than just copy Greek and Indian techniques - their additional researchers developed and systematized several fields of mathematics. ${ }^{6}$ They absorbed Babylonian and Greek astronomy and constructed large-scale astronomical observatories and made measurements against which predictions of Ptolemy could be checked. In the course of their studies, they made several in-depth investigations in Geometry, Diophantine Analysis, and Combinatory. Numbers, particularly numbers as used in algebra fascinated the Islamic mathematicians. Surely, if one measures Islamic mathematics against the ancients, it would be in algebra where their originality and depth is most clearly evident. ${ }^{7}$

Rifaat Y.Ebied in his article entitled Arab and Islamic Contributions to European Civilization explains the field of Astronomy and Chemistry is an early field of Science dominated by Muslims, so Muslims are keen to explore those fields from more Greek civilization yet it is closely related to the skills and practical knowledge of life. ${ }^{8}$

Significantly, the study of astronomy is necessary for the mastery of mathematical knowledge that contributes to the commercial, for example in measuring the time, rates and certain distance in determining the time of

\footnotetext{
5 Ali Akbar Velayati, Ensiklopedia Islam \& Iran: Dinamika Budaya Dan Peradaban Islam Yang Hidup (Bandung: Mizan, 2010), 121.

6 Julian A. Smith, "Arithmetic in Islamic Mathematics," in Encyclopaedia of the History of Science, Technology, and Medicine in Non-Western Cultures (Dordrecht: Springer Netherlands, 2008), 240, doi:10.1007/978-1-4020-4425-0_8445.

7 G. Donald Allen, "The History of Mathematics," Texas A\&M University Mathematics, accessed November 11, 2017, http://www.math.tamu.edu/ dallen/masters/hist_frame.htm.

${ }^{8}$ Rifaat Ebied, "Arab and Islamic Contributions to European Civilization," in Technology Tradition and Survival: Aspects of Material Culture in the Middle East and Central Asia, ed. Richard Tapper and Keith Mclachlan (London: Frank Cass, 2005), 15.
} 
prayer and the date of the calendar. The combination of theoretical knowledge and the proficiency of mastering astronomy in later astronomical sciences developed in Spain further affects Europe. This is evidenced by the use of certain phrases in English which are derived from Arabic, such as the Scorpion (Scorpion) constellation is derived from the word Acrab (from Arabic Aqrab); the flyer of the phrase Altair (Arabic al-ta'ir), the tail (tail) of Deneb (Arabic dhanab), and the word zenith and nadir used until today is the contribution of Islamic scholars in Andalus, Spain ${ }^{9}$.

The Qur'an, the sacred book of Islam, praised mathematic as an art close to God, while Astronomy and astrology were believed to be a pathway to discover God's will. The word āhād in the Qur'an is the first number, one (1) as a symbol of the recitation of the knowledge associated with the existence of God. Mathematics is a part of the essential Islamic sciences in life. The tendency of practising Islamic culture as a way of life affects the development of mathematical science in Islamic civilization. For example, in determining of Qibla direction, the faraid knowledge (inheritance), Islamic art and calculating charity (zakat).

The history of astronomy and mathematics in medieval Islamic society is in particular need of a broader historical interpretation of its development, for historians of Islamic astronomy and mathematics have tended, even more than medical historians, to restrict themselves to analysing the theoretical contents of the extant texts. Further consideration must be given to the interaction of scientific intellectual traditions with technical problems, industrial concerns and constraints, military requirements, timekeeping needs, shifting imperatives of public policy, and educational and religious institutions. The role in society of astronomers, astrologers, mathematicians, physicians, and others learned in scientific matters, both within and outside the courts, could well be

\footnotetext{
9 Ebied, "Arab and Islamic Contributions to European Civilization.", 15.
}

explored, as could the place of instrument makers in the scientific and medical communities. ${ }^{10}$

In addition, the foundations of mathematical knowledge can be observed through the construction of Baghdad City on the order of Caliph al-Mansur in $762 \mathrm{AD}$ and completed in 766-767 AD. This round city has four entrances through two layers of walls. From each entrance, there is an arcade path leading to the city centre where the caliph's palace and the mosque are located. Building materials are from burned bricks, gypsum plaster, mudbrick, and wood. Some people are involved as advisers to urban construction that are not necessarily led by an architect. For example, al-Hajjaj bin Artat was responsible for managing the city's structural and mosque construction, while an engineer named Rabah was responsible for building the city wall. On the plan of a compilation of the city, on the inside of the wall is divided into four parts which each part is managed by a team consisting of an agent, vicar of vicar and architects ${ }^{11}$.

From the above-mentioned background, it is important to highlight the contribution of several Muslim scholars to knowledge productions, especially in Mathematics. Until recently, there is a few review has been made to expose Muslim scholars influence in science. This article explores Muslim scholars involment in the development of Mathematics.

\section{B. RESULT AND DISCUSSION \\ 1. Muslim Scholars Involvement in The Development in Mathematics}

\section{a. Al-Khawarizmi}

Muhammad bin Mūsa al-Khawarizmī (780 - 850) as his name suggests, he or his family, came from Khorezm, a Persian town, today

10 Emilie Savage-Smith, "Gleanings from an Arabist's Workshop: Current Trends in the Study of Medieval Islamic Science and Medicine," ISIS 79, no. 2 (June 1988), 248, doi:10.1086/354701.

11 Donald R Hill, "Science and Technology in Islamic Building Construction," in Technology Tradition and Survival: Aspects of Material Culture in the Middle East and Central Asia, ed. Richard Tapper and Keith Mclachlan (London: Frank Cass, 2005), 47. 
located in northern Uzbekistan. Latin translation of his work al-Kitāb Limukhtașar fi Hisāb li Jabri wa al- Muqābalah (A compendium of Calculus of gebr and muqabala) introduced into Mathematics the term algebra. The first part of al-jabr is manual for solving linear and quadratic equations. Therefore, he is recognized as one of the greatest mathematicians ever lived. His name has been immortalized in another term, algorithm, which attests to the influence of his lost work on the decimal representation of numbers and arithmetic operations. The title of this work was Hisāb Li Hindi Calculus of the Hindus). ${ }^{12}$

\section{b. Tāàbit bin Qurrah}

Tâabit bin Qurrah (826-901) a native of Harran, a town in Northern Syria is an author of A Treatise On the Justification of the Algebraic Problems by Geometric Proofs. He studied number theory (he proved a theorem providing a method for finding pairs of amicable numbers); corrected an earlier translation of the Elements ${ }^{13}$.

\section{c. Abū al-Karaji}

Al-Karaji (953-1029) a commentator of Diophantus formulated the rules of multiplication of polynomials, important for later Arabic 'algebraists' (Wodzicki 2005). He gave numerical solution to equations of the form $a x 2 n+b x n=c$ (only positive roots were considered). He proved:

$$
1^{3}+2^{3}+\cdots+10^{3}=(1+2+\cdots+10)^{2}
$$

...in such a way that it was extendable to every integer. The proof is interesting in the

\footnotetext{
12 Khalid Al-Khateeb, "Science and Technology in Islam." (Kuala Lumpur: University Malaysia, 2001), 12. See Tahir Abdurrahman, Abubakar Abdul, and Auwal Halabi, "The Historical Contributions of Islamic Civilization in Medical and Applied Sciences: A Survey From the Muslims Product," E-Journal of Arabic Studies \& Islamic Civilization 2, no. March (2015), 43. See Also Raghib As-Sirjani, Sumbangan Peradaban Islam Pada Dunia (Jakarta: Pustaka alKaustar, 2009), 347. 2 .
}

sense that it uses the two essential steps of mathematical induction. Nevertheless, this is the first known proof. Al-Karaji's mathematics, differ from other Arab mathematics, pointed to the direction of Renaissance mathematics. ${ }^{14}$

\section{d. Ibn al-Ḥayțam}

Abū Ja'far Muhammad ibn al-Ḥusay alKhāzin (Latin Alhazen, 965-1040) was a mathematician and astronomer who lived in the early tenth century $\mathrm{AD}$ in Khorasān (Helaine Selin 2008). He was author of numerous works on optics, spherical geometry, number theory (he is credited with discovering Wilson's Theorem: "for any prime $p$, $1+(p-1)$ ! is divisible by $p$ " long before Wilson), and several other contributions ${ }^{15}$.

\section{e. 'Umar al-Khayyam}

'Umar al-Khayyam (1048-1131) is a famous Persian poet from Nishapur (born and died there). He was equally celebrated as a mathematician, particularly renowned for his study of cubic equation. During his stay in Samarkand (today Uzbekistan), he composed his most famous mathematical work: Treatise on Demonstration of Problems of Algebra ${ }^{16}$. He worked on the issues surrounding the parallel postulate.

Using the quadrilateral, he discovered an approach to the investigation that became standard. He discovered exactly what must be showed to prove the parallel postulate, and it was upon these type of ideas that non-Euclidean geometry was discovered. Khayyam also argued that rational numbers should be encompassed as numbers, departing from the Greek tradition, whose influence was then and was to remain a powerful force in mathematics and philosophy until the 19th century. He also discovered methods of root extraction to an arbitrarily high degree. He discovered (in Algebra) a geometrical method to solve

\footnotetext{
${ }^{14}$ Allen, "The History of Mathematics."

${ }^{15}$ Wodzicki, "Early History of Algebra: A Sketch.", 3.
} 
cubic equations by intersecting a parabola with a circle but, at least in part, these methods had been described by earlier authors such as Abu al-Jud. To see the construction, consider the circle and parabola

$$
(x-a)^{2}+y^{2}=a^{2}+c^{2}
$$

Substitute and simplify to get

$$
y=x^{2}+b x+c ; x\left(x^{3}-2 b x^{2}-x-2 c x-x b^{2}+2 a-2 c b\right),
$$

which factored gives

$$
x\left(x^{3}+2 b x^{2}+\left(1+2 c+b^{2}\right) x+2 c b-2 a\right)=0 .
$$

So, the intersection $\mathrm{x}$ is the solution of the cubic:

$$
x^{3}+2 b x^{2}+\left(1+2 c+b^{2}\right) x+2 c b-2 a .
$$

Khayyam was an outstanding mathematician and astronomer. His work on algebra was known throughout Europe in the Middle Ages, and he also contributed to a calendar reform. Khayyam refers in his al-jabr book to another work of his which is now lost. In that lost work, Khayyam discusses Pascal's triangle but the Chinese may have discussed triangle slightly before this date. The algebra of Khayyam is geometrical, solving linear and quadratic equations by methods appearing in Euclid's Elements.

Khayyam also gave important results on ratios giving a new definition and extending Euclid's work to include the multiplication of ratios. He poses the question of whether a ratio can be regarded as a number but leaves the question unanswered. Khayyam's fame as a poet has caused some to forget his scientific achievements which were much more substantial. Versions of the forms and verses used in the Rubaiyat existed in Persian literature before Khayyam, and few of its verses can be attributed to him with certainty. ${ }^{17}$

\section{f. Sharf al-Dīn al-Ṭ̂ūì}

\footnotetext{
${ }^{17}$ Allen, "The History of Mathematics."
}

Sharf al-Dīn al-Ṭusīi, (1135-1213) is a native of Tus, a town in north-eastern Persia. He left us a treatise on cubic equations which goes beyond what had been achieved by Khayyam. He used a method of finding approximate solutions which is essentially the Ruffini-Horner method. ${ }^{18}$ Let us consider his analysis of the equation $x^{3}+d=b x^{2}$. He began by putting the equation into the form $x^{2}(b-x)$ $=d$. He then noted that the question of whether the equation has a solution depends on whether the "function" on the left side reaches the value $d$ or not. To determine this, he needed to find a maximum value for the function.

Although he did not tell us how he did so, he claimed and then proved that the maximum value occurs when $x=2 b / 3$, which in fact gave the functional value $4 b^{3} / 27$. Thus Sharaf al-Din could now claim that if this value is less than $d$, there are no (positive) solutions; if it is equal to $d$, there is one solution at $x=2 b / 3$, and if it is greater than $d$, there are two solutions, one between 0 and $2 b / 3$ and one between $2 b / 3$ and $b$. Sharaf al-Din still could not figure out an algorithm to determine these solutions, but at least he knew the basic conditions on whether the solutions existed. Unfortunately, his work was not developed further, either in Islam or later in Europe. So an attempt in Islam to formulate "functions" ultimately got nowhere. One of the reasons, perhaps, is that Sharaf used no symbols - and dealing with functions without symbols is very difficult ${ }^{19}$.

There are many new theory found and developed by Islamic scholars in mathematics, such as number theory, arithmetic, algebra and geometry.

\footnotetext{
${ }^{18}$ Wodzicki, "Early History of Algebra.", 4.

19 Victor J. Katz and Bill Barton, "Stages in the History of Algebra with Implications for Teaching," Educational Studies in Mathematics 66, no. 2 (September 2007), p.192, doi:10.1007/s10649-0069023-7.
} 
2. Contributions Muslim Scholars Involvement in The Development in Mathematics

\section{a. Number theory}

The nine Sanskrit characters found in the Indian astronomical book Sindhinda (Sindhnata) have had a lot of impact on the development of the number system used today around the world. In the 9th century, al-Khwarizmi used it as a place value in a system of 10, also known as the Indian system, as well as altering the symbols of sunya as sifr (zero) meaning empty. This number system was later modified by the Islamic mathematical scholar in Spain by creating the second version of the symbols $1,2,3,4,5,6,7,8,9$ and 0 , also known as the Arabic-Spanish system, also known as the al system al-ghubar. Then it was brought to Europe by the name of the gobar system or Ghuber Numerals and spread throughout through the Spanish Islamic study centre, while the eastern part of the Islamic region remained in its original symbols until now. ${ }^{20}$

\section{b. Quadratic Equations}

Al-Khawarizmi classifies equations into six types, three of which are mixed quadratic equations. For each type, he presents an algorithm for its solution. For example, to solve the quadratic equation of the type "squares and numbers equal to roots" $\left(x^{2}+x=\right.$ $b x$ ), al-Khawarizmi tells his readers to take half the number of 'things', square it, subtract the constant, find the square root and then add it to or subtract it from the half the roots already found. As in Babylonian times 28 centuries earlier, the algorithm is entirely verbal. There are no symbols. Having written down an algorithm, al-Khawarizmi justifies it using a "cut-and-paste" geometry, very much like the Babylonians. But once the justifications are dispensed with, al-Khwarizmi only expects the reader to use the appropriate algorithm. This is different from the Babylonian procedure, in which each problem

\footnotetext{
${ }^{20}$ Smith, "Arithmetic in Islamic Mathematics.”, 241.
}

indicates some use of the geometric background. ${ }^{21}$

Other differences with his Babylonian predecessors, al-Khwarizmi virtually always presents abstract problems, rather than problems dealing with lengths and widths. Most of the problems, in fact, are similar to this one:

I have divided ten into two parts, and having multiplied each part by itself, I have put them together, and have added to them the difference of the two parts previously to their multiplication, and the amount of all this is fifty-four.

The equation translating this problem is $(10$ $-x)^{2}+x^{2}+(10-x)-x=54$. Al-Khawarizmi reduces this to $x^{2}+28=11 x$ and then solves according to his algorithm. Al-Khawarizmi does, however, have one or two other types of problems:

You divide one dirham among a certain number of men, which number is 'thing.' Now you add one man more to them, and divide again one dirham among them; the quota of each is then one-sixth of a dirham less than at the first time.

Al-Khawarizmi describes how to translate this problem into the equation $x^{2}+x=6$; he can then use one of his algorithms to find that $x=2$.

Algebra has now moved decisively from the original geometric stage to the static equation-solving stage. Al-Khawarizmi wanted to solve equations. And an equation has one or two numerical answers. His successors in the Islamic world do much the same thing. They set up quadratic equations to solve and then solve them by an algorithm to get one or two answers. You may notice that I am only talking here about quadratic equations. Surely, Islamic mathematicians solved linear equations. $^{22}$

${ }^{21}$ Victor J. Katz and Bill Barton, "Stages in the History of Algebra with Implications for Teaching," Educational Studies in Mathematics 66, no. 2 (September 2007), 191, doi:10.1007/s10649-006-90237.

${ }^{22}$ Victor J. Katz and Bill Barton, "Stages in the History of Algebra with Implications for Teaching." 
In his al-jabr, al-Khawarizmi has numerous problems solvable by linear equations, mostly in his section on inheritance problems. But to a large extent, solved linear equations was part of what we would call arithmetic, not algebra. That is, the basic ideas were part of proportion theory, an arithmetical concept. Over the next few centuries, Islamic mathematicians worked out various ideas in algebra. They developed all the procedures of polynomial algebra, including the rules of exponents, both positive and negative, and the procedures for dividing as well as multiplying polynomials. Yet the goal of these manipulations was to solve equations, and since the Islamic mathematicians could not solve equations of degree higher than two by an algorithm, they developed two alternative methods. First, there was a return to geometry, but a more sophisticated geometry than Euclid's. 'Umar Khayyam found a way to solve cubic equations by determining the intersection of particular conic sections. A second alternative, and one that was certainly more useful, was to determine numerical ways of approximating the solution, ways closely related to what has become known as the Horner method. Still, of course, the idea was to find a single answer (or maybe two or three) (Katz \& Barton 2007).

\section{c. Geometry}

In mathematics, Abū Ja'far al-Khāzin is mainly known because he was the first to realize that a cubic equation could be solved geometrically by means of conic sections. AlMāhānī (ca. AD 850) had shown that an auxiliary problem in Archimedes' On the Sphere and Cylinder, which Archimedes had left unsolved. Abū Ja'far knew the commentary to Archimedes' work by Eutocius of Ascalon (fifth century AD), in which Eutocius discusses a solution of the same auxiliary problem by means of conic sections. Abu Ja'far drew the conclusion that the equation $x 3 b c^{1 / 4}$ ax 2 could also be solved by means of conic sections. Abū Ja'far also studied a number of other mathematical problems. He stated that the equation $x 3$ b y 3
$1 / 4 \quad z \quad 3$ did not have a solution in positive integers, but he was unable to give a correct proof. He also worked on the isoperimetric problem, and he wrote a commentary to Book $\mathrm{X}$ of Euclid's Elements. ${ }^{23}$

According to Galileo Galilei in his work Saggiatore states that "the universe is written in mathematical language and the letters are triangles, circles and other geometrical shapes". ${ }^{24}$

Geometry from a language angle is taken from the Greek word, geo, which means the earth and metric, which means measure. In terms of science, geometry is the science that studies things in relation to magnitude and space properties. ${ }^{25}$ The application of geometric concepts can be seen through intimate interaction with art in the production of the Egyptian pyramids, Parthenon and Colosseum monuments in ancient Egypt and ancient Greece. The result of geometric forms is able to produce complex and compelling forms and complex patterns. ${ }^{26}$

This era also includes numerous career and trade professions including architects, engineers, surveyors, development experts, entrants, carpenters, masons, archaeologists and labourers. Thousands of workers are given and managed by organizations that oversee modern development projects. One of the phrases used for modern Arabic engineers is muhandis. It is derived from the root word handasa which refers to the meaning of engineering or geometry. This shows that the most important science used by Islamic architects is the science of geometry which is

23 Jan P. Hogendijk, “Abū Ja'far Al-Khāzin,” in Encyclopaedia of the History of Science, Technology, and Medicine in Non-Western Cultures (Dordrecht: Springer Netherlands, 2016), 241, doi:10.1007/978-94007-7747-7_9197.

${ }^{24}$ Ahmad Ashraf Ahmad Shaharudin, "Matematik Dan Seni," Menemui Matematik 33, no. 2 (2011), 31.

${ }^{25}$ Frank J. Swetz, "Geometry," in Encyclopaedia of the History of Science, Technology, and Medicine in Non-Western Cultures (Springer, Dordrecht, 2016), 1000, doi:10.1007/978-94-007-7747-7_8615.

${ }^{26}$ Ahmad Ashraf Ahmad Shaharudin, "Matematik Dan Seni," Menemui Matematik 33, no. 2 (2011), 31. 
a branch of mathematical science. The components of the medieval stone building consist of 3 main elements: gates, poles and walls. While the roof is made of wood or stone. All building elements cannot be linked to mathematical analysis until the $19^{\text {th }}$ century. An analysis of the gates involved complex mathematics, but medieval architects succeeded in establishing it. This is because they have empirical knowledge of the materials and forms that exist so they are able to translate the idea of the architecture. $^{27}$

The $10^{\text {th }}$ century witnessed the excellence of Ghyas al-din Abu al-Fātih Ibn Ibrahìm alKhayyam or better known as 'Umar Khayyam who succeeded in attracting the attention of Sultan Malik Syah and was given great funding for deep research in mathematics and astronomy. He proved that a geometric problem can be solved by some algebraic functions by introducing a partial equation. In addition, he also defines and co-ordinates coordinate geometry in the plane when making an analytic on cone cuttings, including ellipses, circles, parabolic and hyperbole for solving cubic equations. ${ }^{28}$ Subsequently, geometric knowledge continues to evolve with a deeper study in the construction of polygons that have $\mathrm{n}$ boundaries in the $12^{\text {th }}$ century. Among the geometrics involved in the study are al-Mahāni, Abu al-Jūd and Ibn al-Hayțam. Meanwhile, al-Kindi develops a geometric sphere that touches on the concept of modern topology, which is how the sphere can be as horizontal loops in homeomorphism. ${ }^{29}$

\section{The Quran as The Inspiration of Muslim Scholars in Mathematics}

The discovery of al-Khwarizmi on arithmetic is a result of the outcome of his analyses

27 Donald R Hill, "Science and Technology in Islamic Building Construction," in Technology Tradition and Survival: Aspects of Material Culture in the Middle East and Central Asia, ed. Richard Tapper and Keith Mclachlan (London: Frank Cass, 2005), 47.

${ }^{28}$ J.L. Berggren, Episodes in the Mathematics of Medieval Islam (New York: Springer, 2003), 12.

${ }^{29}$ Randy K Schwartz, "Islam \& Mathematics: A Hidden History," 2014, 10. on verses of the Qur'an which indicate the greatness of Allah. Among them is the calculation of the day and year as in the Quran:

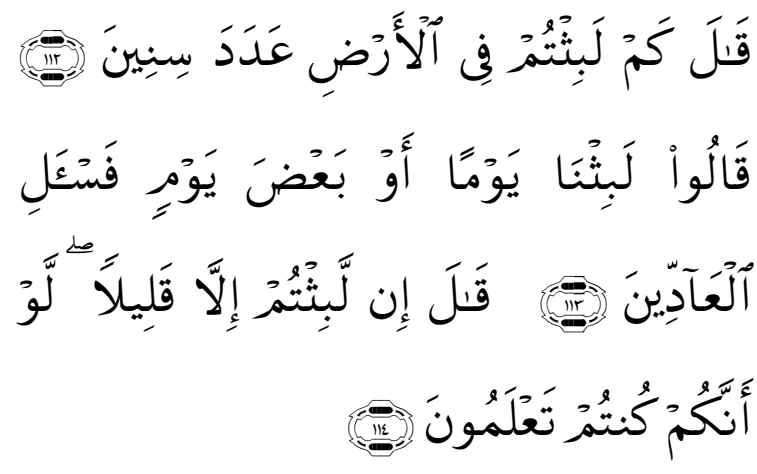

He will say: How many years did you tarry in the earth? They will say: We tarried a day or part of a day, but ask those who keep account. He will say: You did tarry but a little-- had you but known (it). (Quran 23: 112-114)

While fractions and decimal numbers are the result of Muslim scholars who take the idea of the Quran verses:
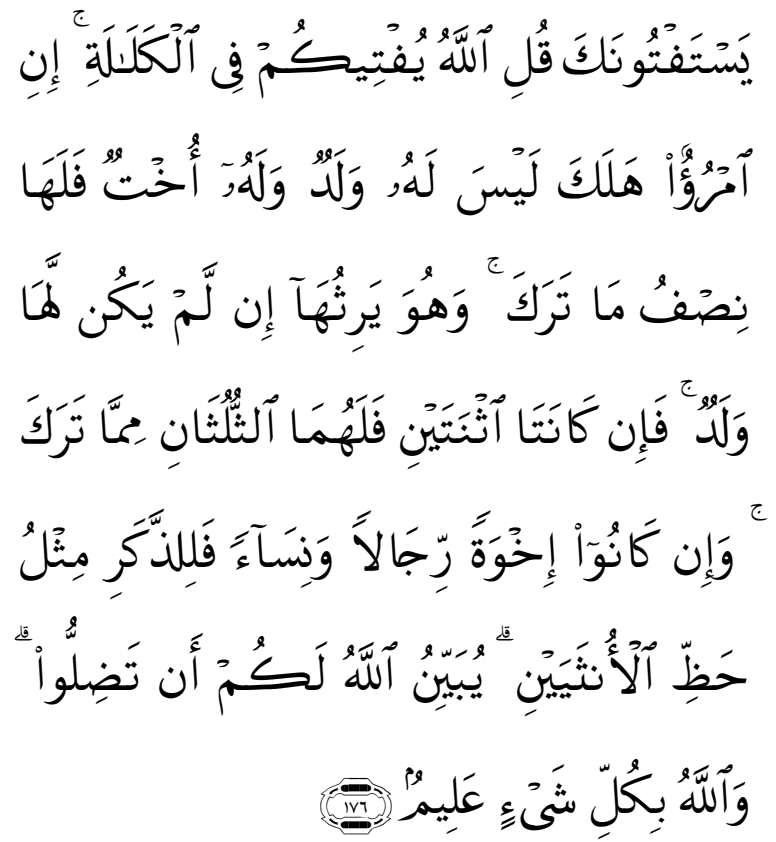

They ask you for a decision of the law. Say: Allah gives you a decision concerning the person who has neither parents nor offspring; if a man dies (and) he has no son and he has a sister, she shall have half of what he leaves, and he shall be her heir she 
has no son; but if there be two (sisters), they shall have two-thirds of what he leaves; and if there are brethren, men and women, then the male shall have the like of the portion of two females; Allah makes clear to you, lest you err; and Allah knows all things. (Quran 4: 176)

Thus Quranic rules for distribution of estates of a deceased Muslim to various relatives, are complicated and their application calls for some skills in arithmetic and algebraic equations. ${ }^{30}$

Al-Hasan Abū Kamal has used fractions and decimal numbers to write and its discovery was popularized in the West by Abraham Ben Reza and Fibonacci through the $17^{\text {th }}$ century gold ratio. In its emphasis on learning, Islam began to fill a chasm that had been widening in the world of the $7^{\text {th }}$ century. The major civilizations had waned, and Europe was in its Dark Ages, while Islam's geographic expansion was matched by an intellectual and cultural fervor. The Qur'an has proved an important stimulus to learning. The word ${ }^{c} i l m$ (knowledge) occurs in the Qur'an about 750 times, one of the highest word counts in the text and one of the most repeated words in the Traditions of the Prophet Muhammad. In addition, the Qur'an clearly distinguishes humans from the rest of creation by their ability to reason. The language is rich in its descriptions of scientific concepts and other areas of knowledge. The Qur'an's language was, and still is, repeated via attentive recitation and heard throughout a Muslim's life. Muslim science of chemistry developed a century and a half after the advent of Islam. Muslims made significant advances in mathematics, as well, with Muhammad ibn Musa's algorithm and development of algebra, geometric solutions, degree measurements, and trigonometric tables .

30 Noor Muhammad Awan, "Quran and Mathematics-I," Jihāt Al-Islām 3, July-December (2009), 51.

31 A. Essa and O. Ali, Studies in Islamic Civilization: The Muslim Contribution to the Renaissance

\section{CONCLUSION}

The development of mathematical knowledge in the highlights of Islamic civilization as early as the $9^{\text {th }}$ century through the $12^{\text {th }}$ century saw the emergence of various scholars and new knowledge that became the cornerstone of modern mathematical science today. There are certain names to be considered as giving significant contributions to science, especially Mathematics. They are al-Khawarizmì, Țābit bin Qurrah, Al-Karaji, Ibn Hayțam, 'Umar Khayyam, and Sharf alDīn al-Ṭ̂sī to name a few of them. Undoubtedly the process of integration of knowledge with other civilizations such as Greece and India, is significant. However, Islam teaches its followers that wisdom is the property of the believer. Hence wherever they find it, they are more entitled to take it. In addition, the existence of certain verses in the Qur'an is seen as having a relationship with the mathematical sciences utilized by Islamic scholars in developing it, in accordance with the purpose of the Qur'an to be revealed so that human beings can use their common sense in applying for every God's order in the Quran.

\section{BIBLIOGRAPHY}

Al-Khateeb, Khalid. Science and Technology in Islam. International Islamic. Kuala Lumpur: University Malaysia, 2001.

As-Sirjani, Raghib. Sumbangan Peradaban Islam pada Dunia. Jakarta: Pustaka alKaustar, 2009.

Awan, Noor Muhammad. "Quran and Mathematics-I." Jihāt al-Islām 3, no. JulyDecember (2009): 39-59.

Berggren, J.L. Episodes in the Mathematics of Medieval Islam. New York: Springer, 2003.

Ebied, Rifaat. "Arab and Islamic Contributions to European Civilization." In Technology Tradition and Survival: Aspects of Material Culture in the Middle East and Central Asia, diedit oleh Richard

(USA: The International Institute of Islamic Thought, 2012), 13. 
Tapper dan Keith Mclachlan. London: Frank Cass, 2005.

Essa, A., dan O. Ali. Studies in Islamic Civilization: The Muslim Contribution to the Renaissance. USA: The International Institute of Islamic Thought, 2012.

Grabiner, Judith V. "The Centrality of Mathematics in the History of Western Thought." Mathematics Magazine 61, no. 4 (1 Oktober 1988): 220-30. doi: $10.2307 / 2689357$.

Hill, Donald R. "Science and Technology in Islamic Building Construction." In Technology Tradition and Survival: Aspects of Material Culture in the Middle East and Central Asia, diedit oleh Richard Tapper dan Keith Mclachlan. London: Frank Cass, 2005.

Hogendijk, Jan P. "Abū Ja'far al-Khāzin.” In Encyclopaedia of the History of Science, Technology, and Medicine in Non-Western Cultures. Dordrecht: Springer Netherlands, $2016 . \quad$ doi:10.1007/978-94-007-77477_9197.

Katz, Victor J., dan Bill Barton. "Stages in the History of Algebra with Implications for Teaching." Educational Studies in Mathematics 66, no. 2 (September 2007): 185-201. doi:10.1007/s10649-006-9023-7.

-. "Stages in the History of Algebra with Implications for Teaching." Educational Studies in Mathematics 66, no. 2 (18 September 2007): 185-201. doi:10.1007/s10649-006-9023-7.

Kline, Morris. Mathematics in Western Culture. London: Oxford Press, 1953.
Savage-Smith, Emilie. "Gleanings from an Arabist's Workshop: Current Trends in the Study of Medieval Islamic Science and Medicine." Isis 79, no. 2 (Juni 1988): 24666. doi:10.1086/354701.

Schwartz, Randy K. "Islam \& Mathematics: A Hidden History," 2014.

Shaharudin, Ahmad Ashraf Ahmad. "Matematik dan Seni: Menemui Matematik. Vol 33. No. 2: 31-36, 2015." Menemui Matematik 33, no. 2 (2015): 3136.

Smith, Julian A. "Arithmetic in Islamic Mathematics." In Encyclopaedia of the History of Science, Technology, and Medicine in Non-Western Cultures, 240 42. Dordrecht: Springer Netherlands, 2008. doi:10.1007/978-1-4020-4425-0_8445.

Swetz, Frank J. "Geometry." In Encyclopaedia of the History of Science, Technology, and Medicine in Non-Western Cultures. Springer, Dordrecht, 2016. doi:10.1007/978-94-007-7747-7_8615.

Velayati, Ali Akbar. Ensiklopedia Islam \& Iran: Dinamika Budaya dan Peradaban Islam yang Hidup. Bandung: Mizan, 2010.

Wodzicki, M. "Early History of Algebra: A Sketch.” Math 160, 2005.

\section{INTERNET}

Allen, G. Donald. "The History of Mathematics." Texas A\&M University Mathematics. Accessed November 11, 2017. http://www.math.tamu.edu/ dallen/masters/hist_frame.htm. 